\title{
Forest management guidelines based on natural disturbance dynamics: Stand- and forest-level considerations
}

\author{
by Yves Bergeron ${ }^{1}$, Brian Harvey ${ }^{2}$, Alain Leduc ${ }^{3}$ and Sylvie Gauthier ${ }^{4}$
}

\begin{abstract}
Although the concept of forest ecosystem management based on natural disturbance has generated a great deal of interest, few concrete examples exist of FEM principles being put into application. Silvicultural practices that emulate natural disturbances are proposed with examples from the principal vegetation zones of Quebec. With the exception of the large-scale use of careful logging to protect advanced regeneration in ecosystems generally controlled by fire, stand-level silvicultural practices currently used are reasonably similar to natural disturbances, although important differences exist. In contrast, at the forest-level, even-aged management, as is currently practised, rarely permits adequate reproduction of the variety of age classes, stand types, and structural components normally found in the boreal forest. A model that allows an even-aged management approach inspired by natural dynamics is proposed.
\end{abstract}

Le concept d'aménagement écosystémique, soit une approche d'aménagement forestier s'inspirant des perturbations naturelles, suscite de plus en plus d'intérêt auprès des forestiers mais son application concrète en est encore à ses débuts. Des pratiques sylvicoles s'apparentant aux perturbations naturelles sont proposées en donnant des exemples pour les principales zones de végétation du Québec. À l'exception de l'utilisation à grande échelle de la coupe avec protection de la régénération et des sols dans des écosystèmes généralement contrôlés par les incendies, les pratiques sylvicoles réalisées couramment à l'échelle des peuplements sont assez similaires aux perturbations naturelles, bien qu'il existe encore des différences importantes. Par contre, l'aménagement normal des forêts équiennes, tel que pratiqué actuellement, permet rarement de reproduire adéquatement la variété des classes d'âges, des types de peuplements et des composantes structurales habituellement rencontrés en forêt boréale. Un modèle permettant d'appliquer une approche d'aménagement équienne s'inspirant de la nature est proposé.

\section{Introduction}

The past decade has seen an increasing interest in forest ecosystem management and, in particular, in forest management strategies that attempt to emulate natural disturbances (Attiwill 1994, Galindo-Leil and Bunnell 1995, MacDonald 1995, Lieffers et al. 1996, Bergeron and Harvey 1997, Angelstam 1998). Although a general consensus has not been reached on the matter, there is considerable agreement that a management approach that maintains stand composition and structures similar to those that characterize natural environments could provide a means of maintaining biodiversity and the essential functions of forest ecosystems (Franklin 1993, McKenney et al. 1994, Gauthier et al. 1996), the logic being that organisms are probably best adapted to the environmental forces with which they have survived and evolved over the millennia. However, despite a great deal of interest and some serious initiatives in this approach, many of the concepts have yet to be put into application on a broad scale. Indeed, while the literature generally presents guiding principles of natural disturbance-inspired forest management, few go as far as proposing silvicultural treatments and management strategies that facilitate its practical

\footnotetext{
${ }^{1}$ Groupe de recherche en écologie forestière, Université du Québec à Montréal, CP 8888 Succ. Centre-Ville, Montréal, QC H3C 3P8. E-mail: bergeron.yves @ uqam.ca

${ }^{2}$ Unité de recherche et de développement forestiers de l'Abitibi-Témiscamingue, Université du Québec en Abitibi-Témiscamingue, 445 boul. de l'Université, Rouyn-Noranda, QC J9X 5E4. E-mail: brian.harvey@uqat.uquebec.ca ${ }^{3}$ Groupe de recherche en écologie forestière, Université du Québec à Montréal, CP 8888 Succ. Centre-Ville Montréal, QC H3C 3P8. E-mail: r13064@er.uqam.ca

${ }^{4}$ Natural Resources Canada, Canadian Forest Service, Quebec Region, 1055 du P.E.P.S., Sainte-Foy, QC G1V 4C7. E-mail: sgauthier@cfl.forestry.ca
}

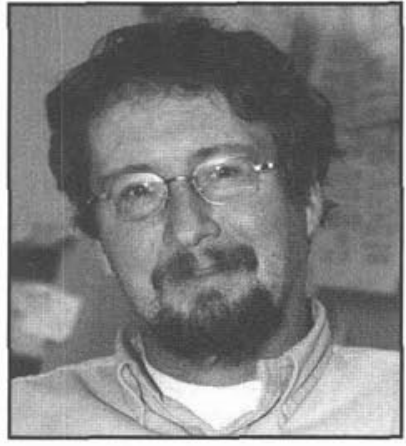

Yves Bergeron

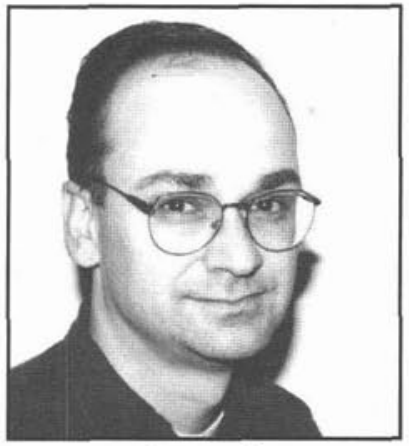

Alain Leduc

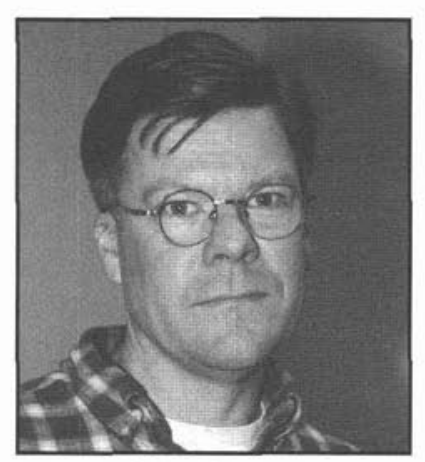

Brian Harvey

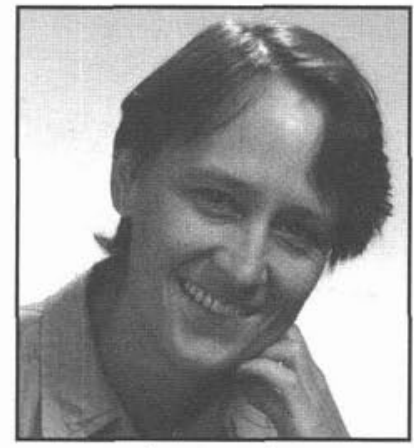

Sylvie Gauthier application. In the absence of concrete alternatives, it is normal that many forest companies hesitate to waiver from traditional practices that have already proven themselves. This article explores certain avenues that advance the links between natural disturbances, silvicultural practices and forest management 


\begin{tabular}{|c|c|c|c|c|}
\hline $\begin{array}{l}\text { Severity of } \\
\text { disturbance }\end{array}$ & $\begin{array}{l}\text { Geographic } \\
\text { extent }\end{array}$ & $\begin{array}{l}\text { Example of } \\
\text { natural disturbances }\end{array}$ & $\begin{array}{l}\text { Associated } \\
\text { Silvicultural practices }\end{array}$ & $\begin{array}{l}\text { Major } \\
\text { differences }\end{array}$ \\
\hline \multirow[t]{3}{*}{$\begin{array}{l}\text { Without direct } \\
\text { effects on advanced } \\
\text { regeneration or soil }\end{array}$} & Small & $\begin{array}{l}\text { Falling of a few trees creating small } \\
\text { gaps in tolerant hardwood forests }\end{array}$ & $\begin{array}{l}\text { Selection cut mimicking natural } \\
\text { mortality of individuals or small } \\
\text { groups of trees }\end{array}$ & $\begin{array}{l}\text { Lack of exposure of mineral soil } \\
\text { results in a loss of germination } \\
\text { beds }\end{array}$ \\
\hline & Moderate & $\begin{array}{l}\text { Windthrow over small areas in the } \\
\text { tolerant hardwood mixed-wood } \\
\text { forest }\end{array}$ & $\begin{array}{l}\text { Group selection cutting mimicking } \\
\text { natural mortality of groups of trees } \\
\text { (Gap selection cutting) }\end{array}$ & $\begin{array}{l}\text { Lack of exposure of mineral soil } \\
\text { results in a loss of germination } \\
\text { beds }\end{array}$ \\
\hline & Large & Spruce budworm outbreak & $\begin{array}{l}\text { Careful logging with advanced } \\
\text { regeneration and soil protection }\end{array}$ & $\begin{array}{l}\text { Absence of snags and residual } \\
\text { trees }\end{array}$ \\
\hline \multirow{3}{*}{$\begin{array}{l}\text { Advanced } \\
\text { regeneration } \\
\text { mortality and } \\
\text { disturbance of } \\
\text { humus layer }\end{array}$} & $\begin{array}{l}\text { Small to } \\
\text { moderate }\end{array}$ & $\begin{array}{l}\text { Surface fires in white and red } \\
\text { pine stands }\end{array}$ & $\begin{array}{l}\text { Clear-cutting with seed-tree } \\
\text { retention }\end{array}$ & $\begin{array}{l}\text { Soil does not burn } \\
\text { Decrease in wood volumes } \\
\text { Absence of snags }\end{array}$ \\
\hline & Moderate & $\begin{array}{l}\text { Fire of variable severity occurring in } \\
\text { mixed forests and leaving a number } \\
\text { of green forest island residuals }\end{array}$ & $\begin{array}{l}\text { Clear-cutting over small areas } \\
\text { followed by seeding or planting }\end{array}$ & $\begin{array}{l}\text { Soil does not burn } \\
\text { Decrease in wood volumes } \\
\text { Absence of snags }\end{array}$ \\
\hline & Large & $\begin{array}{l}\text { High severity fires occurring in the } \\
\text { coniferous boreal forest that burn } \\
\text { soil organic layers }\end{array}$ & $\begin{array}{l}\text { Clear-cutting over large areas } \\
\text { followed by seeding or planting }\end{array}$ & $\begin{array}{l}\text { Soil does not burn } \\
\text { Decrease in wood volumes } \\
\text { Absence of snags }\end{array}$ \\
\hline
\end{tabular}

strategies and demonstrates how a good understanding of natural forest dynamics may be used judiciously in forest management planning and in choosing or developing silvicultural practices. A particular emphasis will be placed on the importance of diversifying silvicultural practices throughout the forest landscape.

\section{Silviculture Adapted To Different Forest Regions}

Many stand level silvicultural practices have repercussions similar to the effects produced by natural disturbances. Table 1 summarizes this point by comparing the severity (at the stand level) of diverse natural disturbances and the silvicultural treatments with which a certain commonality of effects exists. The examples are roughly drawn from a gradient of silvicultural treatments used from southern to northern Quebec; however, the same type of comparison may be applied to other forest regions in Canada.

Although in reality there exists a gradient of natural disturbance severity, Table 1 presents a distinction between two general classes of disturbances, considered at the stand level: those that principally affect the forest overstory (e.g., insect outbreaks and wind-induced stem breakage) and those that affect the overstory as well as advanced regeneration and soil organic layers (e.g., fire). Certain silvicultural practices may be associated with these two large disturbance classes. For example, groupor single stem- selection cutting, now a commonly used practice in most tolerant hardwood forests (Macjen 1994) has effects similar to those caused by naturally formed gaps in this forest type. In the same way, "careful logging," in which harvesting machinery traffic is restricted to parallel, evenly-spaced trails, (a practice widely used in Quebec and Ontario), is well adapted to pure stands of balsam fir that are naturally controlled by spruce budworm outbreaks (Baskerville 1975, MacLean 1984, Bélanger 1993). While somewhat similar in appearance to natural disturbances, these silvicultural practices do nonetheless exhibit certain distinct features. During selection cutting, a lack of soil disturbance may limit establishment of tree species requiring exposure of mineral soil for germination and increase the dominance of species already present or those that regenerate vegetatively. Another example is provided by careful logging. Although the effects of this harvest treatment may be similar to those resulting from a spruce budworm outbreak, careful logging does not necessarily generate the vertical structure nor the abundance of characteristic snags of postbudworm stages.

In contrast, this same practice, when applied in stands normally controlled by fire, has much greater repercussions on the type of natural regeneration of these stands. Natural stands of fire origin are principally regenerated from seed as advanced regeneration is generally destroyed by the fire. This generality does not apply to stands of intolerant hardwoods (poplar and birch), however, because, as is the case after fire, these stands often regenerate vegetatively after forest harvesting. The fact that advanced regeneration of tolerant softwoods may be favoured by certain silvicultural practices can, in certain cases, accelerate forest succession by facilitating replacement of species that have difficulty regenerating in the understory (e.g., jack pine) by species, like balsam fir and white spruce, normally found in the understory. Seed tree cutting or clearcutting followed by planting or seeding may constitute a desirable alternative for stands driven by fire (Table 1). For example, clear-cutting and planting is still a widespread practice in jack pine stands where the absence of advanced regeneration does not always justify the use of careful logging techniques. However, this practice represents an additional silvicultural cost and generally remains out of public favour.

In the absence of site preparation, the effects of clear-cutting resemble only superficially those of forest fires. While there is considerable controversy concerning the consequences of forest harvesting on nutrient recycling and long-term fertility of soils in forests that are naturally driven by fire (MacLean et al. 1983, Binkley and Richter 1987, Brais et al. 1995), there is evidence that scarification or controlled burning prior to plant- 


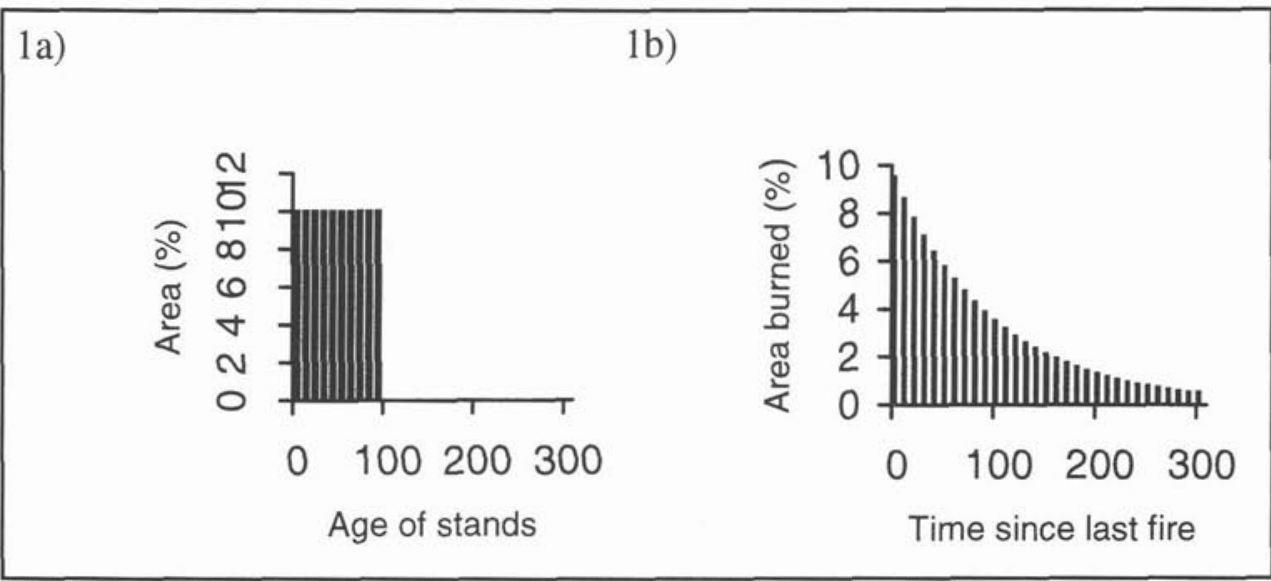

Fig. 1. Forest age-class distribution (by 10-year periods) as a function of a) a fully regulated even-aged forest on a 100-year rotation and b) a 100-year fire cycle.

ing or seeding may modify the soil environment and affect nutrient cycling in a manner similar to that of natural fire. To date, studies on post-fire, seed-origin and post-harvest, layer-origin black spruce have not demonstrated significant differences in height growth between seed- and layer-origin regeneration (Morin and Gagnon 1992). However, the fact that fire in the black spruce boreal forest generally produces even-aged stands of seed-origin while careful logging more often creates layer-origin, uneven-aged stands raises some question as to the sustainability of this practice. Furthermore, the abundance and structure of biomass left on clear-cuts has little in common with the situation of a burned-over forest. In effect, numerous snags as well as residual forested islands of various configurations and sizes, characterize most natural burns. There is still little known about the potential effects of the replacement of fire by clear-cutting and careful logging on the resilience and biodiversity of these forest ecosystems.

\section{Toward A Diversification Of Silvicultural Practices At The Forest Landscape Level}

Although the development of silvicultural practices inspired by natural stand dynamics represents a laudable objective for assuring the maintenance of ecological processes at the stand level, this approach alone can not guarantee the maintenance of biodiversity at both the stand and the landscape scales. At least conceptually, management of ecosystem diversity should consider the composition and structure of stands at the scale of the entire natural forest. In forest regions that lend themselves naturally to uneven-aged management, management strategies are somewhat simplified: While silvicultural choices such as cutting cycle and level of reserve growing stock may vary according to stand type and site conditions, there is relatively little need for concern for maintenance of landscapelevel diversity. Most of the challenge in managing these forests occurs basically at a local level and consists in maintaining species, adequate stocking and stem diameter diversity during the silvicultural prescription. Thus, depending on ecological conditions, the best adapted species should be favoured. It is important, however, to vary the intensity and spatial arrangement of cuts in order to maintain species requiring different light and seedbed conditions.

When the length of the forest rotation approaches that of the disturbance cycle, even-aged management fairly closely resembles large amplitude natural disturbances like fire or insect outbreaks. However, a regulated even-aged forest does not produce an age-class distribution equivalent to that of conditions produced under a natural disturbance regime. In even-aged management a fully regulated forest exists when stand age-classes are distributed uniformly over the entire forest area. Thus, an area managed on a 100-year rotation will contain no stands over the rotation age (Fig 1a).

The same area submitted to forest fires will have, at equilibrium, a completely different age-class distribution of stands. In assuming that the probability of burning is independent of stand age (which is generally reported in the literature for boreal forest studies; Johnson 1992), the age-class distribution of stands issued from fire would follow a negative exponential in which $37 \%$ of stands are older than the fire cycle (Johnson and Van Wagner 1985; Fig. 1b). This means that for a fire cycle equivalent to the forest rotation, forest management will not leave any stands over the rotation age whereas fire will maintain greater than a third of the area over this age. This difference is fundamental because it implies, under fully regulated, even-aged management, the loss of over-aged forests, often judged essential to biodiversity maintenance, or a decrease in allowable cut due to longer forest rotations if the natural disturbance cycle is strictly adhered to. The apparent incompatibility of these situations is not without a solution. The use of silvicultural practices designed to maintain specific structural characteristics of over-mature stands in forests under management may provide a means of maintaining species and ecosystem diversity while only slightly modifying allowable cut.

To this end it would be possible to treat some stands by clearcutting followed by planting or seeding, homologous to fire, others by partial cutting or careful logging, which simulate the natural evolution of over-mature stands, and still others by selection cutting as a means of emulating gap dynamics in old growth. A simple example illustrating the natural dynamics and an ecosystem approach to managing the black spruce boreal forest is presented in Figure 2.

In assuming an invasion by black spruce after fire, an initial cohort is established, characterized by a dense and evenaged stand of seed-origin black spruce. At maturity, this stand will gradually be replaced by a more open stand composed of both seed-origin stems that established immediately after the fire and regeneration that established later primarily 


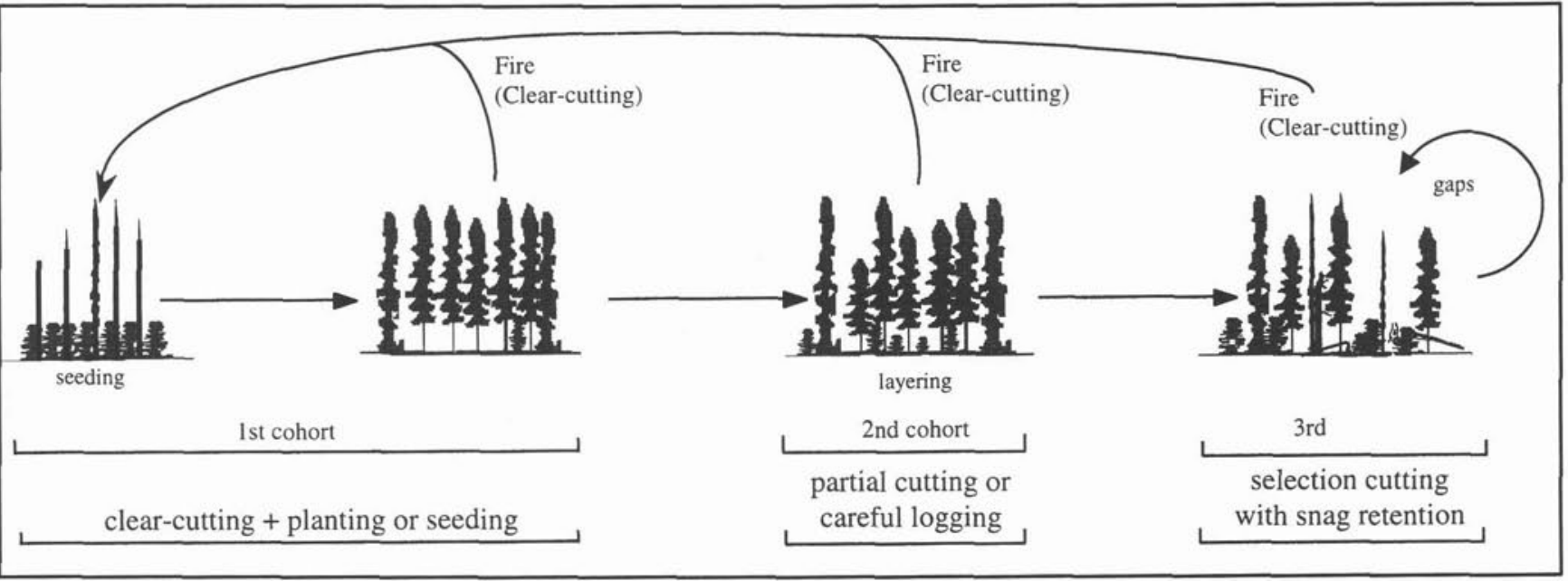

Fig. 2. Natural dynamics and proposed silviculture for the black spruce forest.

from layering. In the absence of fire, these stands evolve toward uneven-aged stands that are principally maintained by layering and characterized by heterogeneous structure and accumulations of woody debris. In varying silvicultural practices (Fig. 2), it would be possible to recreate comparable stand structure. Thus, the first cohort, originating from fire, is replaced by clear-cutting and planting or seeding, the second cohort by partial cutting that emulates natural succession, and the third cohort by selection cutting that mimics the natural gap dynamics of old growth stands. The proportion of stands that should be treated by each of these silvicultural practices should vary in relation to the natural disturbance cycle and the maximum harvest age. Just as in natural landscapes where not all stands survive to a mature or old growth stage before being burned and recommencing succession, not all stands pass through the three cohorts. Reinitiation of the first cohort may be generated by clear-cutting and planting or seeding of stands of any of the three cohorts. Figure 3 provides an example of possible forest age-class structure for stands having a maximum harvest age of 100 years submitted to a natural disturbance cycle of 100 years. The process provides a means of overlaying the area with subgroups of regulated, even-aged forests, but in decreasing proportions as a function of time since the last clear-cut. It is important to note here that the third cohort includes all age classes over 200 years. In the case where stands take longer to reach a state of near-equilibrium, more than three cohorts could be necessary, whereas in the case of short fire cycles and rotations, two cohorts could be sufficient. It would thus be possible to partially recreate not only the natural composition and structure of stands, but also a forest age structure that approaches the typical distribution produced by fire (Fig. 1b).

The basis for this approach can be applied to any number of situations; one only has to know the natural fire cycle and the maximum harvest age to determine the relative areas of each cohort that should be maintained over the forest landscape. Silvicultural practices would vary according to the cohort and the specific disturbance regime of a region. In Table 2 , we present an abacus that allows determination of the proportion of the management cohorts as a function of fire cycle and maximum harvest age. For this exercise, the maximum harvest age is considered the age at which stand break-up begins; that is, where tree mortality results in significant loss of merchantable

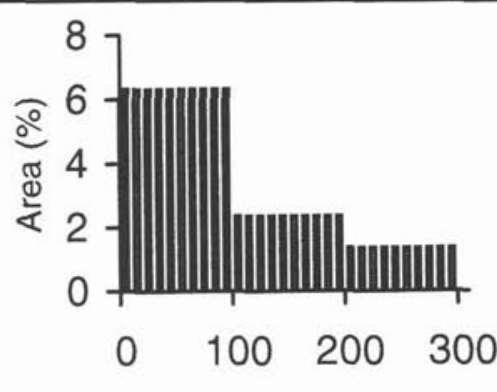

Years since last clear-cut

Fig. 3. Forest age-class distribution (10-year periods) for decreasing 100-year forest rotations.

volume. In this sense, depending on the method used to determine it, the commercial rotation is generally shorter than the maximum harvest age.

With a 50-year fire cycle, a situation similar to that found in northern Alberta (Van Wagner 1978), the great majority of the forest area is composed of the first cohort. This cohort is, however, relatively less important in the more humid climate of eastern Canada, for example in Labrador, where fire cycles of close to 500 years have been reported (Foster 1983). Consequently, clear-cutting (or regeneration cutting of aspen stands) would be an appropriate practice over large portions of forests in the Prairie Provinces, whereas partial cutting with regeneration protection or selection cutting should be more widespread in the East.

Use of the abacus should, however, take into consideration the inherent variability in the calculation of fire cycles and the temporal fluctuations in fire cycle due to climate change. For example, Bergeron et al. (1998) demonstrate that, over a period of 8000 years of the Holocene period, the forest in the Quebec clay belt has been subjected to fire cycles varying between 50 and 500 years. Because vegetation can take an extremely long time to adjust to a particular fire cycle, the current landscape contains stands that are essentially relics from past fire regimes. Moreover, predictions concerning the effects of future climate change suggest changes in fire cycle (Flannigan 
et al. 1988). It is therefore desirable to attempt to maintain all stand types that make up the cohorts, even if strict application of the proposed model would lead to their elimination. This management strategy 1) permits the allocation of a portion of an area to the protection of rare ecosystems; 2) maintains a certain flexibility with respect to future modifications in the wood products market; and 3) allows preservation of the resilience of the forest landscape in the context of changing disturbance regimes.

Modifications in the maximum harvest age also have an important effect on the proportion of the different cohorts over the forest landscape. Thus, for the same fire cycle, the relative area of the first cohort will be proportionally greater where the maximum harvest age is higher (Table 2). For example, the proportion of the first cohort in jack pine stands presenting a higher maximum harvest age will be greater than trembling aspen stands in which break-up occurs at a younger age.

The conjunction between a high maximum harvest age and a short fire cycle places an important limit on the allowable cut of a region, especially in this situation where fires compete with the forest industry for the wood resource. In this instance, the proportion of the first cohort to reach harvest age is naturally smaller than instances where the harvest age is lower. Nature has done fairly well to adjust to this constraint by favouring growth of species whose age at maturity is generally lower than the fire cycle (Johnson 1992).

The values predicted in Table 2 could be modified in the case where successive cohorts have differing maximum harvest ages. This may occur if the passage of one cohort to another involves species replacement or changes in growth rates.

The proposed model emphasizes fire effects because of the near omnipresence of fire in Canadian forests, but it could just as well be applied to disturbances of large amplitudes related to wind or insects that justify the use of even-aged forest management. In these cases, however, the negative exponential model may prove to be inadequate and the proportions of the different cohorts may not correspond to the figures presented in Table 2.

\section{Conclusions}

The management approach presented, while still quite theoretical, may be credited for exploring concrete modes of application. These methods will have to take into consideration the various objectives of implementing sustainable forest management. In effect, we will have to change our perspective of forest ecosystem management: FEM should not consist merely of mimicking Nature, but rather of finding a model in natural dynamics as a means of developing strategies to maintain essential ecosystem functions (e.g., productivity, resilience) and biological diversity. This approach in no way suggests that forest management should attempt to replicate the spatial extent of fire disturbance, for example, by creating contiguous cutting blocks of thousands of hectares. The objective is rather to attempt to draw forest age class structure and composition and stand structure of the managed forest landscape closer to those of the natural landscape. Nor does attaining these objectives necessarily imply developing silvicultural scenarios that mimic natural disturbances. For example, if careful logging, as is currently practised with success in eastern Cana$\mathrm{da}$, maintains fertility and ecosystem diversity as well as a treatment that more closely resembles the real effects of fire, 
it would be inappropriate, even unacceptable, to abandon the practice. In the same way, the use of more intensive treatments such as site preparation and planting should not be avoided if they meet ecosystem management objectives. Extensive silviculture is not, by definition, closer to Nature. Rather, a balance between intensive management and a more naturalbased management is probably the most promising avenue for assuring a continous flow of timber to mills while maintaining some level of forest integrity based on the natural landscape.

It is also important to consider the numerous operational constraints of alternative silvicultural systems. Several projects aimed at exploring new silvicultural approaches inspired by natural dynamics are being undertaken in Alberta (J. Spence, U. of Alberta, pers. comm. 1998), in Ontario (MacDonald 1995) and in Quebec (Bergeron and Harvey 1997). However, we can not wait for the results of these and other studies to change our forest practices. Natural forests are disappearing rapidly in this country, and we now have the responsibility to manage the forest in a sustainable fashion. Moreover, it will be much less costly in the long term to implement practices inspired by nature in our natural forests than to attempt to restore forests that have been subjected to inadequate silvicultural treatments. There is a lesson to be learned from the experience of northern European countries that now have to invest in restoring their natural forests. Our actions must not be taken blindly however; it is important to be able to adapt our interventions as information from monitoring of treatments becomes available.

\section{Acknowledgements}

This article emanates from our participation in the activities of the Network of Centres of Excellence in Sustainable Forest Management and is a contribution of the UQAM/UQAT NSERC Industrial Chair in Sustainable Forest Management. The comments of two anonymous reviewers are gratefully acknowledged.

\section{References}

Angelstam, Per K. 1998. Maintaining and restoring biodiversity in European boreal forests by developing natural disturbance regimes. J. Veg. Sci. 9: 593-602.

Attiwill, P.M. 1994. The disturbance of forest ecosystems: The ecological basis for conservation management. For. Ecol. Manag. 63: 247-300.

Baskerville, G.L. 1975. Spruce budworm: Super silviculturist. For, Chron. 51: 138-140.

Bélanger, L. 1993. Une expérience de gestion écosystémique d'une forêt boréale: le cas de la forêt Montmorency (Québec), dans comptes rendus du congrès conjoint Ordre des ingénieurs forestiers du Québec (OIFQ) et Institut forestier du Canada (IFC), Québec, sept. 1993, pp. F27-F35.

Bergeron,Y. and B. Harvey, 1997. Basing silviculture on natural ecosystem dynamics: An approach applied to the southern boreal mixedwood forest of Quebec. For. Ecol. Manag. 92: 235-242.
Bergeron,Y., P.J.H. Richard, C. Carcaillet, M. Flannigan, S. Gauthier and Y. Prairie. 1998. Variability in Holocene fire frequency and forest composition in Canada's southeastern boreal forest: A challenge for sustainable forest management. Conservation Ecology 2: art. 6 .

Binkley, D. and D. Richter. 1987. Nutrient cycling and H+ budgets of forest ecosystems. Adv. Ecol. Res. 16: 1-51.

Brais, S., C. Camiré and D. Paré. 1995. Impacts of whole-tree harvesting and winter windrowing on soil $\mathrm{pH}$ and base status of clayey sites of northwestern Quebec. Can. J. For. Res. 25: 997-1007.

Flannigan, M., Y. Bergeron, O. Engelmark and M. Wotton. 1998. Future wildfire in circumboreal forests in relation to global warming. J. Veg. Sc. 9: 469-476.

Foster, D.R. 1983. The history and pattern of fire in the boreal forest of southeastern Labrador. Can. J. Bot. 61: 2459-2471.

Franklin, J.F. 1993. Preserving biodiversity: Species, ecosystems or landscapes. Eco. Appl. 3: 202-205.

Galindo-Leal, C. and F.L. Bunnell. 1995. Ecosystem management: Implications and opportunities of a new paradigm. For. Chron. 71: 601-606.

Gauthier, S., A. Leduc and Y. Bergeron. 1996. Forest dynamics modelling under a natural fire cycle: A tool to define natural mosaic diversity in forest management. Environ. Monitoring Asses. 39 : $417-434$.

Johnson, E.A. 1992. Fire and vegetation dynamics-studies from the North American boreal forest. Cambridge Studies in Ecology, Cambridge University Press, Cambridge. 129 p.

Johnson, E.A. and C.E. Van Wagner. 1985. The theory and use of two fire history models. Can. J. For. Res. 15: 214-220.

Lieffers, V.J., R.B. Macmillan, D. MacPherson, K. Branter and J.D. Stewart. 1996. Semi-natural and intensive silvicultural systems for the boreal mixedwood forest. For. Chro. 72: 286-292.

MacDonald, G.B. 1995. The case for boreal mixedwood management: An Ontario perspective. For. Chron. 71: 725-734.

MacLean, D.A. 1984. Effects of spruce budworm outbreaks on the productivity and stability of balsam fir forests. For. Chron. 60: 273-279.

MacLean, D.A., S.J. Woodley, M.G. Weber and R.W. Wein. 1983. Fire and nutrient cycling. In R.W. Wein and D.A. MacLean (eds.). The role of fire in northern circumpolar ecosystems. pp. 111-132. John Wiley \& Sons Ltd., Ottawa.

Majcen, Z. 1994. Historique des coupes de jardinage dans les forêts inéquiennes au Québec. Revue Forestière Française 4: 375-384.

McKenney, D.W., R.A. Sims, F.E. Soulé, B.G. Mackey and K.L.

Campbell (eds.). 1994. Towards a set of biodiversity indicators for Canadian Forests: Proceedings of a forest biodiversity indicators workshop. Sault Ste. Marie, Ontario, Nov. 29-Dec.1, 1993. 133 p.

Morin, H. and R. Gagnon. 1992. Comparative growth and yield of layer and seed-origin black spruce (Picea mariana) stands in Quebec. Can. J. For. Res. 22: 465-473.

Van Wagner, C.E. 1978. Age-class distribution and the forest fire cycle. Can. J. For. Res. 8: 220-227. 